\title{
User-oriented Understanding of Descriptive, Proscriptive and Prescriptive Lexicography*
}

Henning Bergenholtz, Centre for Lexicography, Aarhus School of Business, Aarhus, Denmark (hb@asb.dk)

\begin{abstract}
There is much uncertainty and confusion as to the real differences between prescriptive and descriptive dictionaries. In general, the majority of existing accounts can be summarised as follows: Descriptive relates to the empirical basis; accordance between the empirical data and the dictionary is required. Prescriptive relates to the genuine purpose of the dictionary; the dictionary is meant to help with problems concerning text production and will thus affect usage. This asymmetrical understanding would imply prescriptive and descriptive in practice being false contrasts. In this article, a more consistent terminology is suggested which allows for both the function of the dictionary and the relation of the dictionary to the empirical basis.
\end{abstract}

Keywords: DESCRIPTION, DICTIONARY FUNCTION, EMPIRICAL BASIS, EXACTLY DESCRIPTIVE DICTIONARY, EXACTLY PROSCRIPTIVE DICTIONARY, EXPLICITLY PRESCRIPTIVE DICTIONARY, INTROSPECTION, LINGUISTIC SURVEY, NOT EXACTLY DESCRIPTIVE DICTIONARY, NOT EXACTLY PROSCRIPTIVE DICTIONARY, PRESCRIPTION, PROSCRIPTION, STRONGLY DESCRIPTIVE DICTIONARY, STRONGLY PRESCRIPTIVE DICTIONARY, TEXT CORPUS, USER-ORIENTED, WEAKLY DESCRIPTIVE DICTIONARY, WEAKLY PRESCRIPTIVE DICTIONARY, WEAKLY PROSCRIPTIVE DICTIONARY

Opsomming: Gebruikersgerigte siening van deskriptiewe, proskriptiewe en preskriptiewe woordeboeke. Daar is baie onsekerheid en verwarring oor die werklike verskille tussen preskriptiewe en deskriptiewe woordeboeke. Oor die algemeen kan die meerderheid bestaande verklarings soos volg saamgevat word: Deskriptief hou verband met die empiriese basis; ooreenstemming tussen die empiriese gegewens en die woordeboek is nodig. Preskriptief hou verband met die werklike doel van die woordeboek; die woordeboek is bedoel om te help met probleme betreffende teksproduksie en sal dus gebruik beïnvloed. Hierdie asimmetriese siening sal impliseer dat preskriptief en deskriptief in die praktyk onjuiste teenstellings is. In hierdie artikel word 'n meer konsekwente terminologie aan die hand gedoen wat rekening hou met sowel die funksie van die woordeboek as die verhouding van die woordeboek met die empiriese basis.

Sleutelwoorde: DESKRIPSIE, WOORDEBOEKFUNKSIE, EMPIRIESE BASIS, PRESIES DESKRIPTIEWE WOORDEBOEK, PRESIES PROSKRIPTIEWE WOORDEBOEK, DUIDELIK PRE-

* This article was presented as a keynote address at the Seventh International Conference of the African Association for Lexicography, organised by the Dictionary Unit of South African English, Rhodes University, Grahamstown, 8-10 July 2002. 
SKRIPTIEWE WOORDEBOEK, INTROSPEKSIE, LINGUISTIESE ONDERSOEK, NIE-PRESIES DESKRIPTIEWE WOORDEBOEK, NIE-PRESIES PROSKRIPTIEWE WOORDEBOEK, PRESKRIPSIE, PROSKRIPSIE, STERK DESKRIPTIEWE WOORDEBOEK, STERK PRESKRIPTIEWE WOORDEBOEK, TEKSKORPUS, GEBRUIKERSGERIG, SWAK DESKRIPTIEWE WOORDEBOEK, SWAK PRESKRIPTIEWE WOORDEBOEK, SWAK PROSKRIPTIEWE WOORDEBOEK

\section{Selection}

When you explain something to a layman, it is necessary to make some shortcuts or simplifications. So the following situation is no exception:

Peter (a 12 year old boy): What do you do when you write a dictionary? Of course you write it, but how do you find the words for your dictionary and how do you find the information about these words?

Dr. Claes (a lexicographer working on a large monolingual dictionary): There are, as you know, many words in the language, more than you can include in one dictionary. And you can say very much about each word. If you want to, you can write a whole book about one word. It has, by the way, been done several times already. But I want to make just one book with many words. I do it as follows: First I select the words to be explained in the dictionary. Then I explain the meaning of these words. I also want to show how the words are used. It can be done by examples containing the described word, either short examples with a few words or complete sentences.

Peter: I see. But where do you get all these words, meanings and examples from? And how do you select the right words and explanations? I mean, if you have many more words than you want in your dictionary. And if you have many more meanings and examples. How do you decide what to exclude from or to include in the dictionary? Do you have it all in your head before you start working?

Dr. Claes: Of course I have a lot of knowledge about all the words. That is what a lexicographer has to know. But he can't know everything. Therefore he makes investigations and undertakes searches to find out which words are used and how they are used. Nowadays you have a lot of texts in your computer and you have computer programs to help you. You can produce lists with words or with examples, and the computer can help you find out what kind of meanings and uses of the word are most common.

Peter: I see. Isn't that very exhausting and also quite difficult? If you have more words and meanings in your head or in your computer than you want to include the dictionary, how can you be sure that you make the right choice? To me it looks like visiting my aunt. She always makes wonder- 
ful cakes, but I am not allowed to take more than one. But perhaps it makes enough sense, because if I were allowed to eat all the cakes, I might get a very painful stomach-ache.

In my opinion, Peter has understood one of the main problems in lexicography. What is the best or the most convenient empirical basis for a certain lexicographical project? And what methods can be chosen in the different selection processes (lemma selection, selection of the main orthographical variant, selection of the grammatical variant, selection of collocations, etc.)? In many ways the lexicographer has the same problem as the boy who wants to eat all the cakes. You might say your problem is bigger because the boy did not bake the cakes himself and did not make the choice himself between baking this or another kind of cake. If you do not have a certain type of text in your text corpus (if you do have a corpus as empirical basis), you will of course not have examples of this specific kind in your dictionary (Bergenholtz and Mugdan 1989). You could then say the dictionary is not correctly descriptive, or you could also say it is prescriptive.

\section{Dictionary functions}

It makes no sense however to discuss description contra prescription, before we take a look at what Tarp (2000) calls "the heart of lexicography". The heart of lexicography is the understanding that a dictionary is a tool. And like every tool it has certain functions. A lot of tools have more than one function; they are, like most dictionaries, polyfunctional. The sum of all functions of a given dictionary is called the genuine purpose of the dictionary (Bergenholtz and Tarp 2002). Modern functional lexicographical theory can briefly be described by the following thesis ${ }^{1}$ :

- Lexicography is a discipline in its own right; that means e.g. that lexicography is not a linguistic discipline and not applied lexicology either. On the other hand, specialised lexicography, with its synonym terminography, is part of the discipline lexicography.

Of course, we need linguistic knowledge for a lot of dictionary types, but in the same way we need knowledge about molecular biology preparing an EnglishSpanish biotechnological dictionary and knowledge about music preparing a monolingual music dictionary.

- The object of lexicography is dictionaries. That means the object is not the language, but those tools developed by mankind for certain purposes.

Discussing dictionary functions, you need in the first place to consider the following topics: 
- different types of user situations where the consultation of dictionaries can offer help,

- different types of users distinguished in terms of native language, knowledge of language, general knowledge, specialized knowledge, etc., and

- different types of problems relevant to certain user types in certain types of user situations.

The most important division of functions is one between communication-oriented and knowledge-oriented functions. Through communication-oriented functions the dictionary is a tool helping to solve problems in an ongoing communication. Through knowledge-oriented functions the dictionary is a tool helping the user to extend his knowledge. Each of these sets of functions can be divided into smaller sets or into single functions, e.g. for solving communicative problems through reception or production of text in the mother tongue or in a foreign language. A further division can be made with regard to different user types and their linguistic or encyclopaedic knowledge. Such a typology of dictionaries, e.g. reception dictionaries and production dictionaries for native language users, or translation dictionaries from native language to foreign language for experienced translators, is much more relevant than descriptive terms such as linguistic dictionaries, encyclopaedic dictionaries or mono- and bilingual dictionaries (Bergenholtz 1998).

But let us return to dictionary functions. The considerations mentioned above are also necessary if you aim at a relevant discussion on what kind of empirical basis you need for a specific dictionary and when you decide whether it is better to compile a descriptive or a prescriptive dictionary.

\section{Empirical basis and dictionary functions}

In linguistics there is some but no universal agreement about the use of the terms description and prescription: Normally the first term explains how a language element is used, the second tells you how to deal with a certain language element. This means that description has a clear relation to the empirical basis, prescription to the function of information about language. But besides this very unclear and asymmetric agreement, there are quite different explanations (Bergenholtz 2001). This is not the main topic of this article. Instead of a terminological discussion, I will begin with some data which can be used as part of the empirical basis for a concrete lexicographical project (Bergenholtz 1995). In the following table, are given some results from two linguistic surveys of the Danish language, one with 795, the other with 341 informants. You also find the number of attestations from searching the Internet. In the last column the items from the official Danish dictionary are given. I have chosen orthographical and inflectional variants as examples. But this does not mean that my 
arguments are about lexicographical problems regarding inflectional morphology and orthography only. The same arguments could be applied to all kinds of item types in all kinds of dictionary types.

\begin{tabular}{|l|r|r|r|r|c|}
\hline & \multicolumn{2}{|c|}{ linguistic survey } & \multicolumn{2}{|c|}{ Google } & $\begin{array}{c}\text { official } \\
\text { variant }\end{array}$ \\
\hline linie (line) & 231 & $68.0 \%$ & 102,886 & $71.2 \%$ & - \\
\hline linje (line) & 109 & $32.0 \%$ & 41,572 & $28.8 \%$ & + \\
\hline ludder (prostitute) & 56 & $16.6 \%$ & 233 & $5.8 \%$ & + \\
\hline luder (prostitute) & 281 & $83.4 \%$ & 3,793 & $94.2 \%$ & + \\
\hline frådse (gorge) & 217 & $66.2 \%$ & 412 & $95.2 \%$ & - \\
\hline fråse (gorge) & 111 & $33.8 \%$ & 21 & $4.8 \%$ & + \\
\hline kraftvarmeværk (combined \\
power and heating plant station)
\end{tabular}

\section{Table 1}

In these cases, you have different orthographical variants. Sometimes the variants are used with a clear preference in the linguistic survey and in the Internet texts, e.g. variants linie contra linje (Eng. line) and ludder contra luder (Eng. prostitute). But even in such clear cases, you can see that the normative official Danish Language Council does not decide according to real use: The frequent variant linje (Eng. line) was prohibited in November 2001, but the infrequent form ludder (Eng. prostitute) is still allowed. This tendency is especially clear from the very frequent, but prohibited orthographical variant with -d- in frådse (Eng. gorge) and also from the variant without hyphens kraftvarmeværk (Eng. combined power and heating plant station). In other cases, you see that the informants decided in a way which differs from the real use in texts, e.g. the variant with or without an accent alléen contra alleen (Eng. the avenue), and with -æ- or 
-i- in grundlæggende contra grundliggende (Eng. fundamental). In all these cases, both variants are allowed by the Danish Language Council. And finally you find differences between the answers in the linguistic survey and the real use in texts as shown by the three variants for Eng. vanilla, but only one of these variants is allowed by the Danish Language Council. These Language Council decisions are quite variable, in that they change with every new edition of the official dictionary. The Danish Language Council published a new edition in 1996 with quite a number of changes and another in 2001 with even more changes, e.g. from one form to another: frådse $\rightarrow$ fråse (Eng. gorge), kraftvarmeværk $\rightarrow$ kraft-varme-værk (Eng. combined power and heating plant station), or from two variants to only one: linie or linje $\rightarrow$ linje (Eng. line), or from one variant to two: for resten $\rightarrow$ for resten or forresten (Eng. incidentally). This is in contrast with the English-speaking world which does not have such normative traditions.

At least two interesting points can be made with regard to these variants: (a) It is not very clear whether we can call the decisions made by the Danish Language Council prescriptive, because very often they are quite liberal and allow for two or more variants, even if one of these variants is quite infrequent. (b) There is almost no general public discussion pro or contra these decisions, although every pupil, student or government employee is legally bound to use only the allowed orthographical variants.

The same situation applies to the inflection of verbs, nouns and adjectives. In the following, you see a verb with a clear preference for one inflectional variant (vejledte, Eng. instructed), but the infrequent variant is also allowed together with the frequent one. In the last case, you will find a preference in the linguistic survey for the very frequent variant with the inflection -det for singular definite (postbudet, Eng. the postman), but this variant is prohibited by the Danish Language Council.

\begin{tabular}{|l|r|r|r|r|c|}
\hline & \multicolumn{2}{|c|}{ linguistic survey } & \multicolumn{2}{c|}{ Google } & $\begin{array}{c}\text { official } \\
\text { variant }\end{array}$ \\
\hline vejledede (instructed) & 73 & $9.2 \%$ & 41 & $9.9 \%$ & + \\
\hline vejledte (instructed) & 710 & $89.3 \%$ & 373 & $90.1 \%$ & + \\
\hline both & 6 & $0.8 \%$ & & & \\
\hline don't know & 6 & $0.8 \%$ & & & \\
\hline postbuddet (the postman) & 96 & $28.2 \%$ & 69 & $6.5 \%$ & + \\
\hline postbudet (the postman) & 244 & $71.8 \%$ & 1,434 & $93.5 \%$ & - \\
\hline
\end{tabular}

Table 2

\section{Description}

Collecting and using such data from a linguistic survey and from a text investigation in practical lexicographical work is normally called descriptive lexicography. It can be description, but it need not be. And although the lexico- 
graphical results can be called description, this is not exact. You have to distinguish between different ways and different extents of description. It depends on the empirical basis and its use:

(a) introspection,

(b) analysis of a linguistic survey,

(c) involvement of descriptions in existing dictionaries, grammars, monographs, articles, etc.,

(d) analysis of a number of examples which have been randomly chosen from random texts (corresponding with the practice of dictionary making before the age of computers),

(e) analysis of a specifically constructed text corpus, and

(f) analysis of usage found in texts in the examined language in all available web-sites on the Internet.

These possibilities for an empirical basis can be used in different ways and to different extents. In order to deal with these possibilities, we need suitable terms. They are necessary for drawing a distinction between different kinds of lexicographical work:

open description if the outside matter informs about the empirical basis, or

hidden description if the outside matter does not inform about the empirical basis.

Most dictionaries do not exactly inform about the used empirical basis, therefore they use a hidden description. It is possible that a good part of the dictionary users do not read the outside matter. But interested users, especially critical ones and also linguists, really need an open description. Only then is it possible for them in difficult cases to compare the items with their own considerations, particularly if they encounter the lexicographical treatment of variants. As part of an open description the lexicographer has to explain what kind of description he has used, be it his own competence as an empirical basis, or also the investigation of a text corpus etc.:

total description using a combination of description possibilities (a), (b), (c), (d), (e) and (f), or

partial description using only some of the possibilities for description.

You do not often find that all possibilities have been used. The American Heritage Dictionary and the Danske Netordbog are two of the few examples based on a linguistic survey. (For a theoretical discussion of user survey methods and the representation in dictionaries see Andersen and Bergenholtz 2001.) In the following dictionary articles (see (1)-(10) below), a partial description is given by using possibilities (a), (b), (c) and (f) as empirical basis.

A description, either total or partial, can be given in different ways, depending on the quality of the used empirical basis: 
strong description if the items are given after an analysis of a broad empirical basis, e.g. for description possibility (b) a representative sample, or for description (e) an exemplary corpus (a large and broad text corpus), or

weak description if the items are given after an analysis of a narrow empirical basis, e.g. for description possibility (b) a non-representative sample, or for (e) a small corpus, or if the items are given without any kind of references to a broad empirical basis.

All the following dictionary articles are based on a broad empirical basis, but only articles (1)-(9) can be considered as strongly descriptive; the remainder (10)-(12) would be found in a weakly descriptive dictionary. But there are differences between (1)-(9), which can be called different gradations of descriptivity.

As a last differentiation, a distinction must be made between the exclusion of parts of the empirical results or the inclusion of all the empirical results:

explicit description if all results from every part of the empirical basis are part of the dictionary, also from description possibility (c) obsolete words or meanings, or from description possibility (e) mistakes, or

implicit description if only results from description possibilities (d), (e) or (f) are part of the dictionary, e.g. mistakes are not included as items in the dictionary.

Most dictionaries include some of the more infrequent words or meanings, but normally they do not include mistakes. In both cases such an inclusion could be an advantage for the user who wants to know whether he should or should not use a certain word, word combination or meaning. It could also be advantageous for the user situation, if the user has a text reception problem with an older or a rare word or a misused word, e.g. a frequent spelling mistake.

In dictionary articles (1)-(12) you find different examples, all the result of descriptive lexicographical work, but in quite different ways, depending on the kind of descriptiveness. In dictionary articles (1)-(3) you have descriptive information about the inflection of vejlede (Eng. instruct), all arranged with the infinitive as lemma, followed by the present, the preterite and the past tense:

(1) vejlede verb $\langle-r$, vejledte (710 attestations, 373 informants) or -de (73 attestations and 41 informants), ... $\rangle$

The Danish Language Council allows all inflections mentioned.

(2) vejlede verb $\langle$-r, vejledte $(89 \%)$ or -de $(11 \%)$; similarly the informants $(90 \%$ and $10 \%$ respectively), $\ldots\rangle$

The Danish Language Council allows all inflections mentioned.

(3) vejlede verb $\langle-r$, vejledte (frequent) or -de (rare), vejledt (frequent) or $-\mathrm{t}$ (rare); most informants also chose vejledte and vejledt, ... $\rangle$

The Danish Language Council allows all inflections mentioned. 
Using the same kind of differentiation, the lexicographer can prepare dictionary articles, all descriptive but quite different from each other, depending on the type of lexicographical method used to present the descriptive results. For kraftvarmeværk (Eng. combined power and heating plant station) you have the same inflection, but different variants with or without hyphens:

(4) kraftvarmeværk noun 〈et; -et, -er, -erne $\rangle$ (...)

This spelling without a hyphen is the usual variant (5,495 attestations), besides 90 for kraftvarme-værk, 2 for kraft-varmeværk, 6 for kraft-varme-værk, similarly the choice of the informants with 284 votes for kraftvarmevxrk and 30, 6 and 14 informants respectively for the variants with a hyphen or hyphens. The Danish Language Council allows only the spelling with two hyphens: kraft-varmevark.

(5) kraftvarme-værk $\rightarrow$ kraftvarmeværk

(6) kraft-varmeværk $\rightarrow$ kraftvarmeværk

(7) kraft-varme-værk $\rightarrow$ kraftvarmeværk

(8) kraftvarmeværk noun $\langle$ et; -et, -er, -erne $\rangle(. .$.

This spelling is the most frequent (98\%), only between $2 \%$ and $0.04 \%$ for kraftvarme-værk, kraft-varmeværk and kraft-varme-værk, similarly the informants voted with $85 \%$ for kraftvarmeværk and $9 \%$ for kraftvarme-værk, 2\% for kraft-varmeværk and 4\% for kraft-varmeværk. The Danish Language Council allows only the spelling with two hyphens: kraft-varme-værk.

(9) kraftvarmeværk noun 〈et; -et, -er, -erne (...)

This spelling is the most frequent and is also the preferred informant choice. Other spelling variants with one hyphen are rare and with two hyphens very rare. The Danish Language Council allows only the spelling with two hyphens: kraft-varme-værk.

The following dictionary articles are also descriptive, but they are examples of a weak description where the lexicographer did not have a broad empirical basis, or did not use the results from such an investigation in the descriptive representation of dictionary articles (10)-(12) for vejlede (Eng. instruct) and kraftvarmeværk (Eng. combined power and heating plant station):

(10) vejlede verb $\langle-r$, vejledte/vejledede, vejledt $/-t, \ldots\rangle$ The Danish Language Council allows all inflections mentioned.

(11) vejlede verb $\langle-r$, vejledte/-de, vejledt/-t $\rangle$

(12) kraftvarmeværk or kraft-varmeværk or kraftvarme-værk or kraft-varme-værk noun 〈et; -et, -er, -erne〉

Let us try to look at these dictionary articles from the viewpoint of an imagi- 
nary user. He is a teacher of Danish at a secondary school, and his name is Oskar. Oskar's knowledge of and interest in Danish is on a high level. If he wants to know more about variation in Danish inflectional morphology and orthography, the strongly descriptive dictionary articles (1), (2) and (8) and (9) are very informative; the remaining less strongly and especially the weakly descriptive articles are not relevant for the knowledge-oriented function of a dictionary. If Oskar instead is in doubt about the choice of variants when he encounters text production problems, he will probably choose vejledte and kraftvarmevxrk from dictionary articles (1)-(9), because he wants to follow the normal language usage. But perhaps he will not make his choice from dictionary articles (4)-(9), because he wants to follow the Danish Language Council. The weakly descriptive dictionary articles (11) and (12) are not helpful at all when making a choice of a variant. They only inform Oskar to make the choice himself.

\section{Prescription}

In the Scandinavian countries, you find some preference for descriptive lexicography, but the normal practice is to be more prescriptive, which is also advocated by some metalexicographers. In the USA, you can even find supporters of a purely leave-the-language-alone approach:

It is not the function of a dictionary-maker to tell you how to speak, any more than it is the function of the mapmaker to move rivers or rearrange mountains or fill in lakes. (Urdang 2000: 37)

Neither in specialised lexicography nor in countries like Iceland will it be possible to find many supporters of this approach. The tradition in Africa, e.g. regarding Swahili, but also regarding many other languages, tends towards prescriptive lexicography. As to prescription you have at least the following three possibilities:

(a) a specific linguistic variant is explicitly prohibited,

(b) one or more linguistic variants are explicitly prescribed, thus prohibiting all other non-mentioned variants, and

(c) a specific linguistic variant is explicitly prescribed (as opposed to prescription (b) this involves a new word, new spelling, new pronunciation, new inflection or neologism).

All these possibilities are not used in every dictionary article. For other articles you have the same possibilities using the empirical basis for description mentioned above. A prescriptive dictionary contains prescriptive dictionary articles, but can also contain articles similar to those in e.g. weakly descriptive dictionaries. The point is the user cannot know which article corresponds with language usage and which does not. Therefore it will make no sense to say that 
some of the articles are descriptive and some prescriptive. ${ }^{2}$ Here you may similarly to the proposals for description - distinguish between different lexicographical labelling techniques:

open prescription if the outside matter informs about its intention to influence and in the end change the language use up to now, or

hidden prescription if the outside matter does not inform about its intention to influence and change the language use up to now.

In a prescriptive dictionary, the method of a hidden prescription is a way to seduce the user if the outer text does not inform about the intention of the prescription. Therefore only an open prescription should be the practice in scientifically based dictionaries.

In the next distinction, the dictionary user is not given such clear advice or instruction, for it depends on the function of the dictionary:

total prescription using a combination of prescription possibilities (a), (b) and (c), or

partial prescription using only one or two of the possibilities for prescription.

The term partial prescription will also be used if a dictionary is only prescriptive according to one or only some of the item types, e.g. only by orthographical items. But here you have a clear classification. This is not the case concerning the following terms with a typological division:

strong prescription if dictionary articles have items that prohibit and only allow certain variants in cases with a clear difference from the normal language use, or

weak prescription if dictionary articles have items that prohibit and only allow certain variants in cases with some but not very clear differences from the normal language use.

With such a typological division you might have had more gradations such as very strongly prescriptive, strongly prescriptive, quite prescriptive, weakly prescriptive and very weakly prescriptive. Here a very simple division with an extreme prescription has been chosen in order to designate it as strong prescription. In this sense dictionary articles (13), (14) and (16) are strongly prescriptive. The prohibited variant has a frequency of more than $95 \%$, or the only allowed variant has a frequency of less than $5 \%$. In dictionary articles (15) and (17), you have a weak prescription, because the prohibited variant is less frequent than $95 \%$, or the only allowed variant is more frequent than $5 \%$.

The terms explicit and implicit are not used in the same way as for description. This is necessary, because you have quite another intention with giving advice or instruction to the dictionary user:

explicit prescription if one variant is explicitly allowed and another is explic- 
itly prohibited, or

implicit prescription if one variant is an item and therefore allowed and all other not mentioned variant implicitly prohibited.

The inflection for preterite vejledte (Eng. instructed) is not allowed in dictionaries with dictionary articles (13), (14) and (16), but this variant is the frequent one $(90 \%)$, similarly the prohibited kraftvarmeværk (Eng. combined power and heating plant station). On the other hand, vejlod (Eng. instructed) and kraft-varmewærk (Eng. combined power and heating plant station) are not used in written Danish texts. But this presentation is possible in prescriptive dictionaries, so they may differ from real language usage:

(13) vejlede verb $\langle-r$, de, -t; not allowed: vejledte, vejledt $\rangle$

(14) vejlede verb $\langle-r$, vejlod, vejledt; not allowed: vejledte/vejledede, vejledt/vejledet $\rangle$

(15) kraft-varme-værk noun 〈et; -et, -er, -erne〉

Other spellings without or with only one hyphen are not allowed: kraftvarmeværk, kraftvarme-værk, kraft-varmeværk

Dictionary articles (13)-(15) are explicitly prescriptive, (16)-(17) implicitly prescriptive.

(16) vejlede verb $\langle-r$, de, $-t\rangle$

(17) kraft-varme-værk noun 〈et; -et, -er, -erne〉

When Oskar, our secondary school teacher, is not certain about the choice of variants to solve his text production problems, dictionary articles (13)-(17) would suit him well. These articles would of course not appear in the same, but in different dictionaries, and would give different answers. But if Oskar knows that the dictionary he consults is prescriptive with some items different from normal language use, he will find what he wants: clear advice for text production problems. If Oskar chooses such a dictionary for reception problems, it is quite useful too. In dictionary articles (13)-(16), he will find orthographical and inflectional variants and from there arrive at the correct lemma, and in addition will find some hints about the quality of the texts he reads. He will then find that the texts are faulty because they often use prohibited variants. About knowledge-oriented functions, he will not obtain much information, only about the decisions of the dictionary makers. From the dictionary articles at least he cannot learn why one variant is prohibited or why another one is preferred.

\section{Proscription}

With regard to proscription, you have the same possibilities for the empirical 
basis as with description:

(a) introspection,

(b) analysis of a linguistic survey,

(c) involvement of descriptions in existing dictionaries, grammars, monographs, articles, etc.,

(d) analysis of a number of examples which have been randomly chosen from random texts (corresponding with the practice of dictionary making before the age of computers),

(e) analysis of a specifically constructed text corpus, and

(f) analysis of usage found in texts in the examined language in all available web-sites on the Internet.

If a lexicographer chooses to be proscriptive, the way he deals with the results of the empirical analysis differs from that of being descriptive. The lexicographer does not stop after having informed the user about language use, he also wants to tell the user which variant he should choose if there is more than one possibility. This lexicographical method of presentation can be called proscription, ${ }^{3}$ in practice it is a selective description. Unlike description where every single case is invented individually and described on its own, proscription throughout compares similar cases systematically and makes the same decisions in each case. Proscription does not include all elements from the empirical basis in the dictionary items. The terminological differentiation is similar to that of description:

open proscription if the outside matter informs about the used empirical basis, or

hidden proscription if the outside matter does not inform about the used empirical basis;

total proscription using a combination of proscription possibilities (a), (b), (c), (d), (e) and (f), or

partial proscription using only some of the possibilities for proscription;

strong proscription if the items are given after an analysis of a broad empirical basis, or

weak proscription if the items are given after an analysis of a narrow empirical basis, or if the items are given without any kind of references to a broad empirical basis; and

exact proscription if only one variant is recommended; other variants can be mentioned, or

not exact proscription if more than one variant is recommended; other variants can be mentioned.

In the following dictionary articles, you have exact proscription in (18) and (19) and not exact proscription in (20)-(22) (the examples are the same: vejlede (Eng. 
instruct), kraftvarmeværk (Eng. combined power and heating plant station)):

(18) vejlede verb $\langle-r$, vejledte, $-t\rangle$

The Danish Language Council allows only preterite and past tense vejledede and vejledt, inflections which are not very frequent.

(19) kraftvarmeværk noun 〈et; -et, -er, -erne〉

Other spellings with hyphens are possible: kraft-varmeværk or kraftvarme-værk. They are not recommended. They are quite rare in language use, e.g. by special field experts. The Danish Language Council allows only the spelling with two hyphens: kraft-varmeværk.

(20) vejlede verb $\langle-r$, vejledte, $-t\rangle$

(21) kraftvarmeværk noun 〈et; -et, -er, -erne〉

(22) vejlede verb $\langle-\mathrm{r}$; -de or vejledte; -t or vejledt $\rangle$

If Oskar, our secondary school teacher, encounters text production problems, he could use the dictionary. He might be uncertain about the choice of variant but he gets clear advice in dictionary articles (18) and (19). Contrary to prescriptive dictionary articles, he is advised about language use similar to the normal language use in society. This advice is less clear in the not exactly proscriptive article (22). About knowledge-oriented functions he gets some information, especially in the exactly proscriptive dictionary articles (18) and (19).

\section{Descriptive, prescriptive and proscriptive dictionaries}

In the discussion between Peter and Dr. Claes, Peter had one question more which can only now be addressed at the end of this article:

Peter: It is easy to understand why my aunt makes cakes. She likes it, and people like to visit her and eat her cakes. It doesn't take too long to prepare a cake, but I think it takes many weeks, perhaps more than a year to prepare a dictionary. Are dictionaries really so important that they are worth working on for so long and so hard? What I mean is: what are dictionaries made for?

Dr. Claes: Well listen: dictionaries are tools. There are a lot of tools. You need a knife if you want to cut a twig from a tree. You need glasses, if your eyes are not good enough. You need a dictionary if you don't know something about a word or a thing, that is, if you don't know what a word means, or how a certain word is used. For these different purposes you have different dictionaries. But sometimes you can use one and the same dictionary for different purposes. It is like some knives which have blades for cutting and a corkscrew for pulling the cork out of a bottle. 
According to the function of the different kinds of descriptive, prescriptive and proscriptive dictionaries, this can be explained in the following summary:

Strongly descriptive dictionaries are well suited for knowledge-oriented functions, but also for communication-oriented function reception. They cannot easily be used for text production functions, because they often do not give clear advice, but a lot of confusing information.

Weakly and not exactly descriptive dictionaries are not well suited for any communication- and knowledge-oriented functions.

Exactly the same can be said about weakly and not exactly proscriptive dictionaries: they are not well suited for any communication- and knowledge-oriented functions.

Exactly proscriptive dictionaries are well suited for all kinds of communication-oriented functions in text production.

Strongly prescriptive dictionaries are not well suited for any dictionary functions. It is a question of language policy whether the decision-makers in a language society decide to choose such a lexicographical solution.

Explicitly and weakly prescriptive dictionaries can be well suited for text production in connection with specialised languages. They can be used successfully as part of national and international language politics. But for this function, proscriptive dictionaries are better suited, because they do not differ from current language usage.

A more consistent lexicographical terminology is described in the following table, where the labelling "+ -" in the last row means that the analysis of an empirical basis can, but might not have taken place, and that in some articles there are differences between the items and the normal language use, but perhaps not always (although the user cannot know):

\begin{tabular}{|l|c|c|c|}
\hline & empirical basis & $\begin{array}{c}\text { accordance with } \\
\text { empirical basis }\end{array}$ & $\begin{array}{c}\text { intention to } \\
\text { influence the user }\end{array}$ \\
\hline descriptive dictionary & + & + & - \\
\hline proscriptive dictionary & + & + & + \\
\hline prescriptive dictionary & +- & +- & + \\
\hline
\end{tabular}

Table 3

\section{Endnotes}

1. Modern functional lexicographical theory is quite different from old-fashioned theory, e.g. cf. Wiegand (2001). Such theories are primarily based on the outer type of dictionary, not on the user and the use of dictionaries. 
2. It could only be done for a dictionary with special labelling for descriptive and for prescriptive articles. No such dictionary is known for any language.

3. The term proscriptive is formed according to Latin proscribere 'make public'. The word proscriptive is already in use in English with the meaning 'forbidden', compare a proscriptive law or a proscriptive statement. In order to avoid a conflict Gregory James has proposed the use of praeterscriptive instead of proscriptive. It could indeed be a term for proposal items in lexicography, but proscriptive is already used in quite a lot of lexicographical articles. A terminological change could lead to new misunderstandings. Besides, it is quite common that you find a specific use of a certain word in ordinary language and another use of the same orthographical word in language for special purposes. Therefore, I do not follow the proposal from James.

\section{Bibliography}

Andersen, Henning and Henning Bergenholtz. 2001. Brug af surveys til lingvistiske undersøgelser. Hermes 27: 201-209.

Bergenholtz, Henning. 1995. Material for the Dictionary. Bergenholtz, Henning and Sven Tarp (Eds.). 1995. Manual of Specialised Lexicography. The Preparation of Specialised Dictionaries: 90-96. Amsterdam: Benjamins.

Bergenholtz, Henning. 1998. Das Schlaue Buch. Vermittlung von Informationen für textbezogene und textunabhängige Fragestellungen. Zettersten, Arne, Jens Erik Mogensen and Viggo Hjørnager Pedersen (Eds.). 1998. Symposium on Lexicography VIII. Proceedings of the Eighth International Symposium on Lexicography May 2-5, 1996 at the University of Copenhagen: 93-110. Tübingen: Niemeyer.

Bergenholtz, Henning. 2001. Proskription, oder: So kann man dem Wörterbuchbenutzer bei Textproduktionsschwierigkeiten am ehesten helfen. Lehr, Andrea, Matthias Kammerer, KlausPeter Konerding, Angelika Storrer, Caja Thimm and Werner Wolski (Eds.). 2002. Sprache im Alltag. Beiträge zu neuen Perspektiven in der Linguistik. Herbert Ernst Wiegand zum 65. Geburtstag gewidmet: 499-520. Berlin/New York: De Gruyter.

Bergenholtz, Henning and Joachim Mugdan. 1989. Korpusproblematik in der Computerlinguistik: Konstruktionsprinzipien und Repräsentativität. Bàtori, Istvàn S., Winfried Lenders and Wolfgang Putschke (Eds.). 1989. Computional Linguistics. An International Handbook on Computer Oriented Language Research and Applications. / Computerlinguistik. Ein internationales Handbuch zur computerunterstützten Sprachforschung und ihrer Anwendungen: 141-149. Berlin/ New York: De Gruyter.

Bergenholtz, Henning and Sven Tarp. 2002. Die moderne lexikographische Funktionslehre. Diskussionsbeitrag zu neuen und alten Paradigmen, die Wörterbücher als Gebrauchsgegenstände verstehen. Lexicographica 18: 253-263.

Tarp, Sven. 2000. Theoretical Challenges to Practical Specialised Lexicography. Lexikos 10: 189-208.

Urdang, Laurence. 2000. Review of R.R.K. Hartmann and Gregory James. Dictionary of Lexicography. International Journal of Lexicography 13(1): 35-42.

Wiegand, Herbert Ernst. 2001. Was eigentlich sind Wörterbuchfunktionen? Kritische Anmerkungen zur neueren und neusten Wörterbuchforschung. Lexicographica 17: 217-248. 